\title{
Late-/postglacial age and tectonic origin of the Nordmannvikdalen Fault, northern Norway
}

\author{
Lars Olsen', Odleiv Olesen', John Dehls' \& Georgios Tassis' \\ ${ }^{1}$ Geological Survey of Norway, P.O. Box 6315 Torgarden, N-7491 Trondheim, Norway. \\ E-mail corresponding author (Lars Olsen): lars.olsen@ngu.no
}

The Nordmannvikdalen Fault (NF) represents one of the two observed postglacial faults in Norway. The two faults constitute the northernmost part of the Lapland province of postglacial faults, occurring in large tracts of northern Sweden and northern Finland. The 1.3 km-long, NWSE-trending NF is thought to be a normal fault with scarp height increasing from less than $0.50 \mathrm{~m}$ in the NW to c. $1.50 \mathrm{~m}$ in the SE. A tectonic origin for the Nordmannvikdalen Fault, which seems to be aseismic today, has recently been questioned and alternative causes as either gravitational collapse or overburden creep have been suggested. We carried out three 3-5 m-deep trenches and two ground penetrating radar (GPR) profiles in September 2017 to study the fault at depth. The trenching reveals deformation structures within the lodgement till. The faulting led to cracking of the ground, forming a vertical wedge-shaped crevice, with a width similar to previously recorded large ice wedges and ice wedge casts (fossil ice wedges) in polygonal pattern ground in Arctic areas. The width increases with increasing scarp height, i.e., the vertical displacement. The crevice was filled with sediment, snow and water freezing to ice, with subsequent infilling, during melting seasons, of more debris from the side walls of the host material and cryoturbated and soliflucted soil. The Nordmannvikdalen Fault appears, from the trenching, to have been formed in one single seismic event. The new GPR data show bedrock reflectors dipping approximately $38-45^{\circ}$ towards the NE, below the NF scarp. The average angle of the terrain slope between the Nordmannvikdalen Fault scarp and the valley floor is $14^{\circ}$, and the altitude difference between the fault scarp and the Nordmannvikdalen valley floor is approximately $200 \mathrm{~m}$. We find no reason to downgrade the fault to 'very unlikely to be neotectonics'.

Keywords: Postglacial fault, normal fault, neotectonics, georadar data, sediment wedge, solifluction

Received 19. April 2018 / Accepted 26. November 2018 / Published online 28. February 2019

\section{Introduction}

Two postglacial faults have been suggested on mainland Norway. The NE-SW-oriented, reverse Stuoragurra Fault (Olesen, 1988; Muir-Wood, 1989; Olesen et al., 1992; Dehls et al., 2000) in western Finnmark and the NW-SE-oriented, normal Nordmannvikdalen Fault (Bakken, 1983; Sollid \& Tolgensbakk, 1988; Tolgensbakk \& Sollid, 1988; Dehls et al., 2000) constitute the Norwegian part of the postglacial Lapland Fault Province (Fig. 1). The Nordmannvikdalen Fault is located c. $70 \mathrm{~km}$ to the north of a $130 \mathrm{~km}$-long gap between the Stuoragurra and Pärvie faults, and may represent an accommodation or conjugate fault to the extensive system of NE-SW-trending reverse faults (Olesen et al., 2004). The Nordmannvikdalen Fault is located within the Reisa Nappe Complex in the Upper Allochthon of the Caledonian Orogen, and represents the only northern Fennoscandian postglacial fault outside the Precambrian Shield. The fault is sub-parallel to regional gravity and magnetic anomalies, which are interpreted to represent structures in the underlying Proterozoic basement, situated at a depth of c. $3 \mathrm{~km}$ in this area (Olesen et al., 1990; Dehls et al., 2000).

Olsen, L., Olesen, O., Dehls, J \& Tassis, G. 2018: Late-/postglacial age and tectonic origin of the Nordmannvikdalen Fault, northern Norway. Norwegian Journal of Geology 98, 483-500. https://dx.doi.org/10.17850/njg98-3-09. 


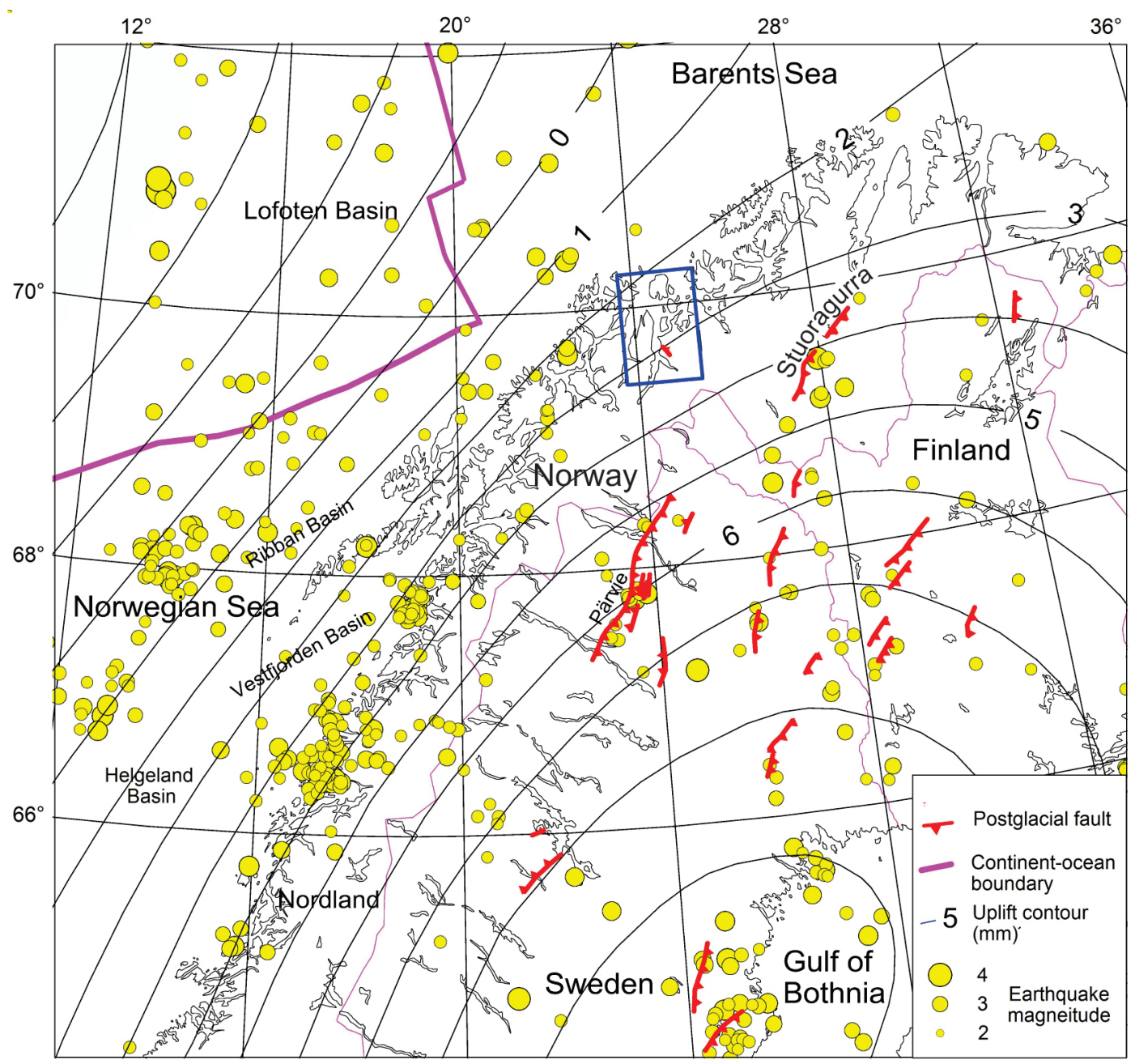

Figure 1. Postglacial faults (Olesen et al., 2013; Mikko et al., 2015; Palmu et al., 2015), land uplift (Vestøl et al., in prep.) and seismicity (19902012) in northern Fennoscandia from the web pages of the Institute of Seismology at the University of Helsinki. A lower threshold at magnitude 2.0 has been applied to reduce contamination by explosives. The Lyngen-Kåfjord area as shown in Fig. 2 is depicted by the blue frame.

There has been speculation of ongoing tectonic activity in the Lyngen area. Holmsen (1916) estimated postglacial uplift from levelling of shorelines in northern Troms. The uplift shows negative anomalies diverging from the regional trend of the order of $5 \mathrm{~m}$ in the Lyngen area. This effect was attributed to the mafic and ultramafic massifs within the Lyngen Magmatic Complex (ophiolite). The interpretation is, however, hampered by poor age control on the formation of the shorelines (Olesen et al., 2004). Redfield \& Hermanns (2016) presented evidence for active faults in the N-Strending Lyngen Fjord and along the NW-SE-trending Kåfjorddalen, Skibotndalen and Signaldalen, as well as along the NE-SW-trending Kågsundet and Maursundet. They based their findings mostly on InSAR data.

The Stuoragurra Fault is located within the regional Mierujavri-Sværholt Fault Zone separating the Proterozoic Kautokeino Greenstone Belt in the NW from the Archaean Jergul Gneiss Complex in the SE. The Stuoragurra Fault consists of numerous sections that commonly overlap, forming an en échelon pattern.
Reverse faults with en échelon structures are described from California, Australia, Basin and Range Province (USA), New Zealand, page 322-355 in Yeats et al. (1997). Postglacial faults in northern Finland show a similar type of en échelon structures. Numerous trenching operations have not revealed any strike-slip components of these faults. The total length of the Stuoragurra Fault is $80 \mathrm{~km}$ with a c. $20 \mathrm{~km}$-wide gap without any apparent faulting in the central part of the fault. The maximum scarp height is $7 \mathrm{~m}$. The dip is $50-60^{\circ}$ implying a maximum reverse displacement of approximately $10 \mathrm{~m}$. The till above the Stuoragurra Fault is folded indicating the presence of a blind thrust.

The interpretation of the character and age of the Nordmannvikdalen Fault (Figs. 2 \& 3) has been based on airphoto-interpretation, trenching and ground penetrating radar (Bakken, 1983; Tolgensbakk \& Sollid, 1988; Sollid \& Tolgensbakk, 1988; Dehls et al., 2000; Redfield \& Hermanns, 2016). Previous studies, with the exception of Redfield \& Hermanns (2016), have related the NF to tectonic faulting. Redfield \& Hermanns (2016) 


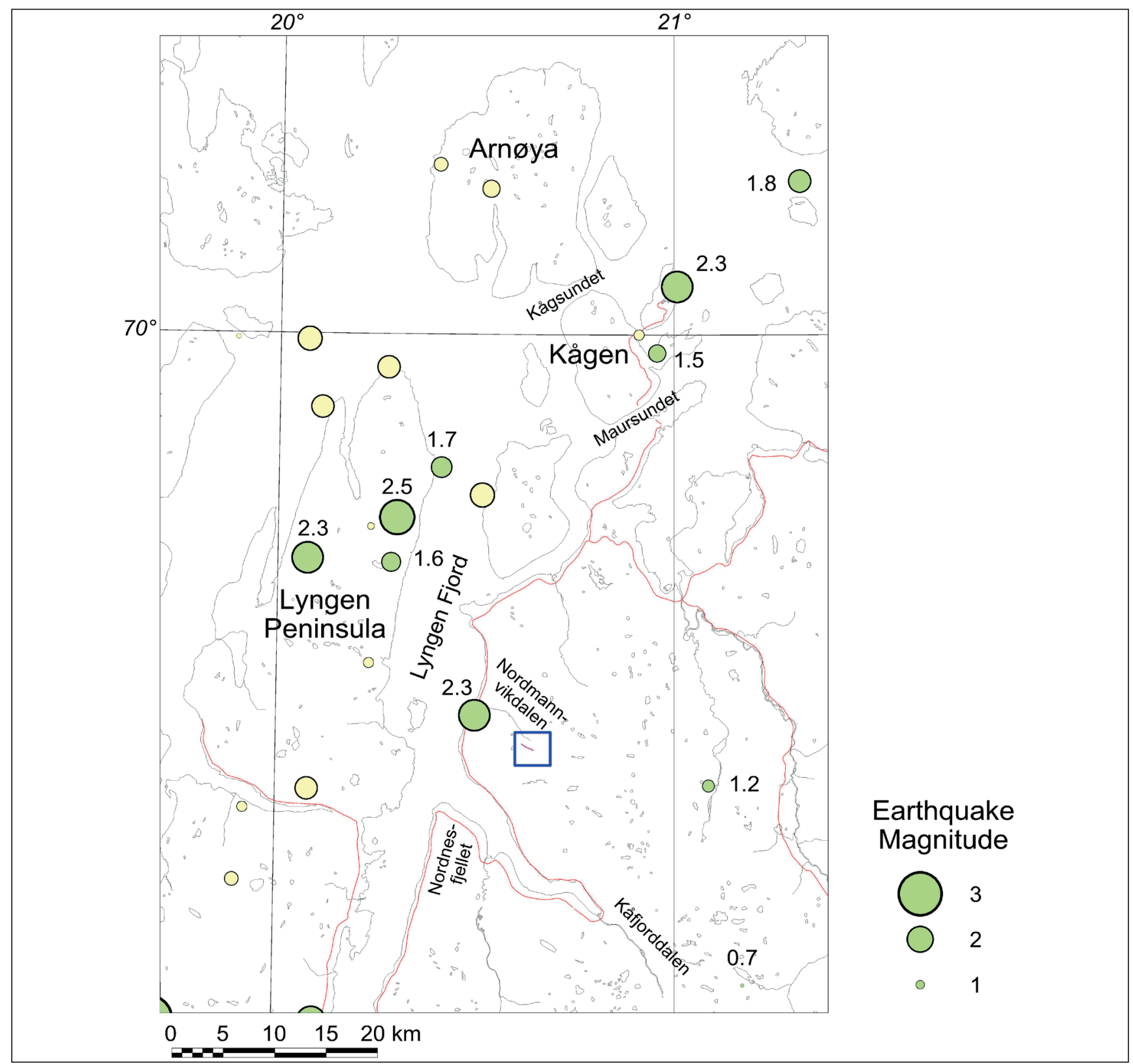

Figure 2. Map of the northern Troms area showing the Nordmannvikdalen Fault in red within the blue frame and earthquakes (pale green and yellow circles). The reported seismic events in the outer Lyngen Fjord (Redfield \& Hermanns, 2016) are based on recordings at the NORSAR seismic array in Karasjok located c. $200 \mathrm{~km}$ to the east. The University of Bergen includes additional recordings from their seismic stations in Tromsø and Kautokeino located 60 and $140 \mathrm{~km}$ to the west and southeast, respectively. These improved epicentres shown in the present map locate around the Lyngen peninsula and the island of Arnøya. The 1999 earthquakes on Arnøya are most likely related to blasting during the molo construction at Arviksand harbour in the winter of 1999 (Olesen et al., 2013). Explosion filtering of the earthquakes remove much of the seismicity in the area (shown in yellow). The filter removes events smaller than magnitude 2.0 occurring between 08:00 in the morning and 18:00 in the afternoon (C. Lindholm, pers. comm., 2017). The location of the map is shown by the blue frame in Fig. 1.

reinterpreted the existing data and carried out a shallow trenching (location shown in Fig. 3) and concluded that the NF was a gravity-induced fault or an overburden creep phenomenon. They could not find any offset of the Quaternary overburden at the fault scarp. Their observation excludes the NF being a Deep-seated Gravitational Slope Deformation structure (DSGSD). Dehls et al. (2000) excluded a gravitational origin for three reasons: 1) The scarp is not arcuate in shape. The curvature seen in map view is due to the topography. 2)
No accommodation structures are observed along the sides of the fault structure. 3) No toe of a reverse fault can be seen along the valley floor.

The fault locally splits into two or three semi-parallel branches (Bakken, 1983; Dehls et al., 2000; Redfield \& Hermanns, 2016). En échelon structures occur especially in the northwestern part of the fault (Fig. 4). The faultbounded depressions along the fault scarp and along 


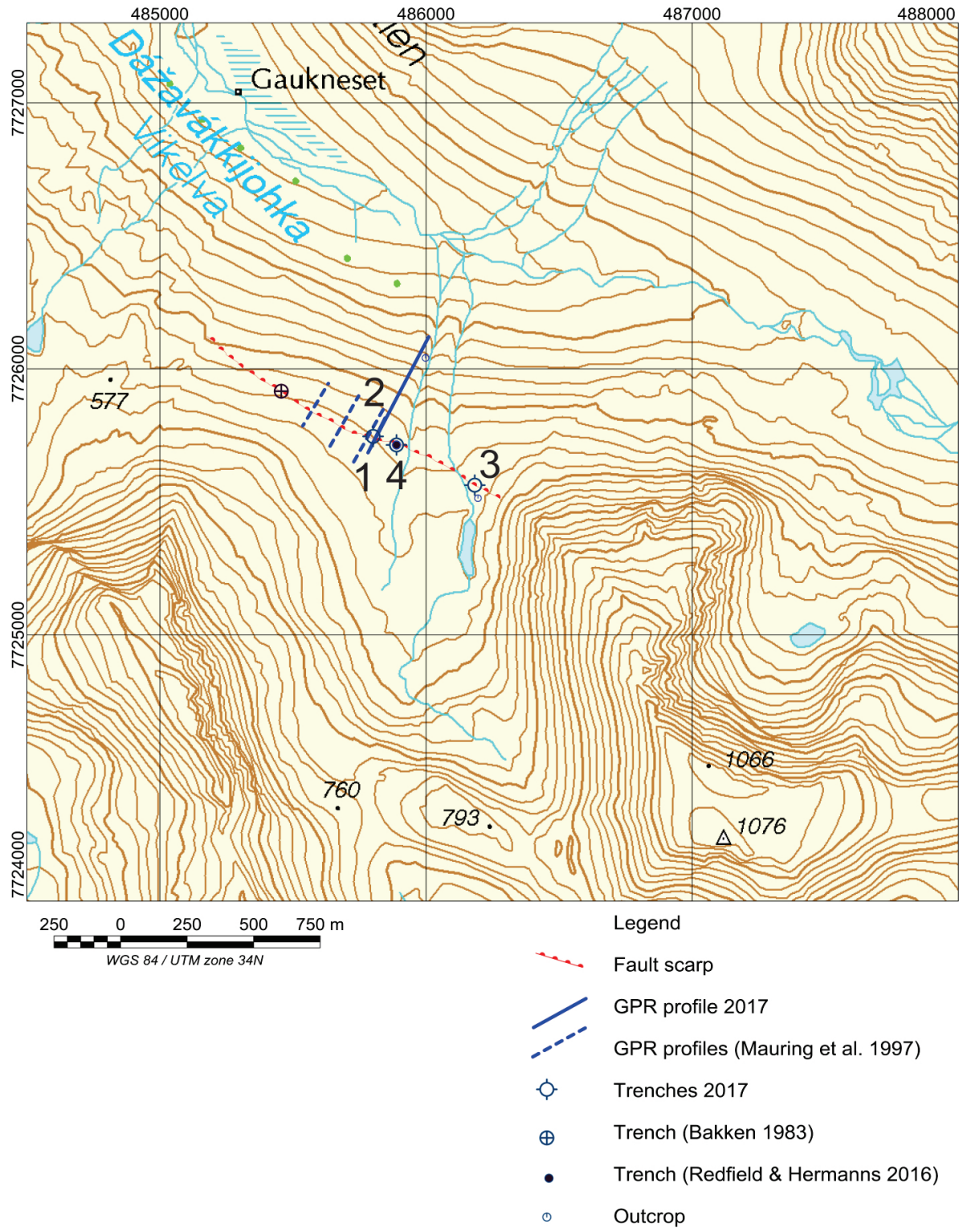

Figure 3. Topographic map of the Nordmannvikdalen area showing the postglacial fault scarp, trenches and bedrock outcrops in addition to the location of the new $50 \mathrm{MHz}$ profile and the previous $50 \mathrm{MHz}$ ground penetrating radar profiles by Mauring et al. (1997) and Dehls et al. (2000). The location of the map is depicted by the blue frame in Fig. 2. Parts of the mountains Nordmannviktinden and Kistefjellet are located in the SW (lower left) and in the SE (lower right), respectively.

the semi-parallel, assumed fault-related lineaments (Fig. 4) most probably occur in the overburden, similarly to normal faults in New Zealand (Beanland et al., 1990; Yeats et al., 1997). There is a high number of rock avalanches in the vicinity of the Nordmannvikdalen Fault indicating a relationship between palaeoseismicity and slope failures (Braathen et al., 2004; Osmundsen et al., 2009). The northwestern end of the scarp terminates against a bouldery moraine from late-glacial ice lobes (Dehls et al., 2000). Due to the large size of the blocks, any ruptures of less than a few metres vertical displacement of the ground surface would be hidden by the big moraine blocks. It is therefore impossible to determine the relative ages of the fault and the moraine which, in addition, was subsequently partially transformed to a rock glacier. It is possible that the moraine conceals the original side of the slump (vertical displacement). However, there is no evidence pointing towards this. The eastern end of the scarp terminates against a scree deposit (Talus) below the Kistefjellet mountain (Figs. $3 \& 4 \mathrm{~A}$ ). Here, there is clearly no evidence of faulting. Since the fault scarp has its maximum height $(c .1 .5 \mathrm{~m})$ at this location, a continuation underneath the scree deposit is likely.

In September 2017, we excavated the overburden in three c. 10-15 m-long and 3-5 m-deep trenches across the scarp of the Nordmannvikdalen Fault, in order to collect additional information in support of or against a neotectonics origin for the fault. In addition, new ground penetrating radar data were collected. 

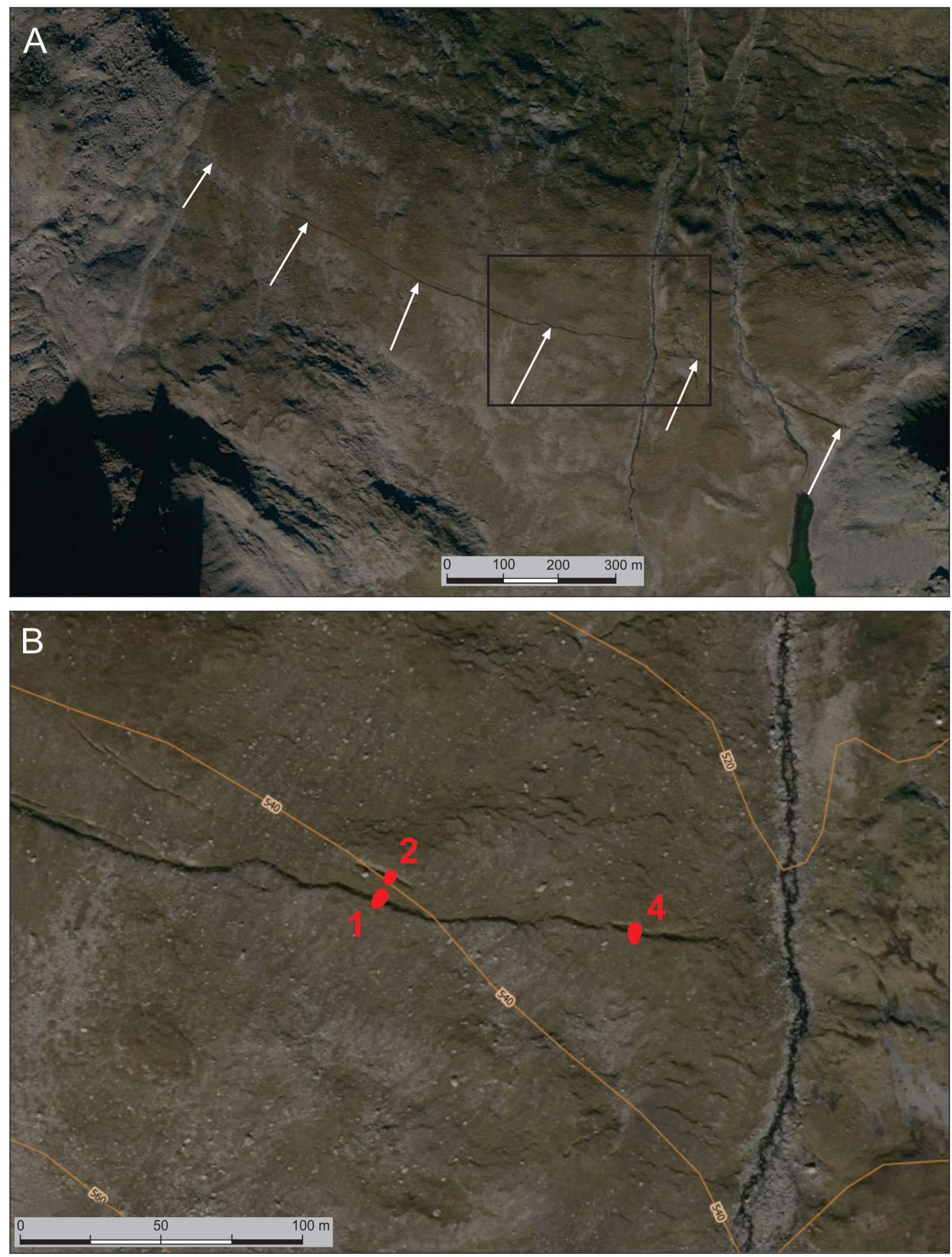

Figure 4. (A) The Nordmannvikdalen Fault which can be observed from the boulder scree deposit in the east (right) to the lateglacial moraine and younger rock glacier deposit in the west (left). (B) The middle part of the Nordmannvikdalen Fault and location of trenches 1, 2 and 4. Trench 4 is also the location where Redfield \& Hermanns (2016) did their trenching in cryoturbated soil across the fault scarp. Photographs are from Kartverket (http://www.norgeskart.no). 


\section{Methods}

\section{Ground Penetrating Radar}

The Ground Penetrating Radar (GPR) technique is probably the most commonly used geophysical method due to quick, easy, inexpensive and non-intrusive collection of data and its ability to thus provide very detailed and continuous images of the subsurface. Mapping of underground layers and/or linear features is based on the propagation and reflection of highfrequency electromagnetic (EM) waves and later processing and interpretation of the resulting radargrams (Jol, 2009). Data were acquired using the Malå RTA system (Snake), since it was easier to transport to the survey area and is more suitable for high inclination terrain. The Snake system utilises an in-line antenna setting enclosed in a flexible cord that allows it to be maneuvered easily and efficiently through dense vegetation and uneven terrain without affecting ground contact. In this sense, two profiles were collected using the $100 \mathrm{MHz}$ antenna and one with $50 \mathrm{MHz}$. All profiles intersected the superficial manifestation of the fault perpendicularly and data were collected starting uphill and walking down towards the base of the valley. The topographic difference in elevation for the longest profile is almost $50 \mathrm{~m}$ over $500 \mathrm{~m}$ of horizontal distance (50 $\mathrm{MHz}$ antenna), therefore a standard migration is essential in order to precisely determine the true geometry of the detected structures and, more importantly, of the fault itself. With the choice of a realistic propagation velocity, migration will again help collapse any possible hyperbolas whose right-hand legs might interfere with interpreting actual dipping lineaments. In this study, the $100 \mathrm{MHz}$ antenna profiles did not return good results, so we will only present the relatively low-frequency $50 \mathrm{MHz}$ radargram since it presents the highest depth penetration and unveils the most meaningful reflections. Data were processed, modelled and interpreted using a RadExplorer v. 1.42 (DECO Geophysical, 2005).
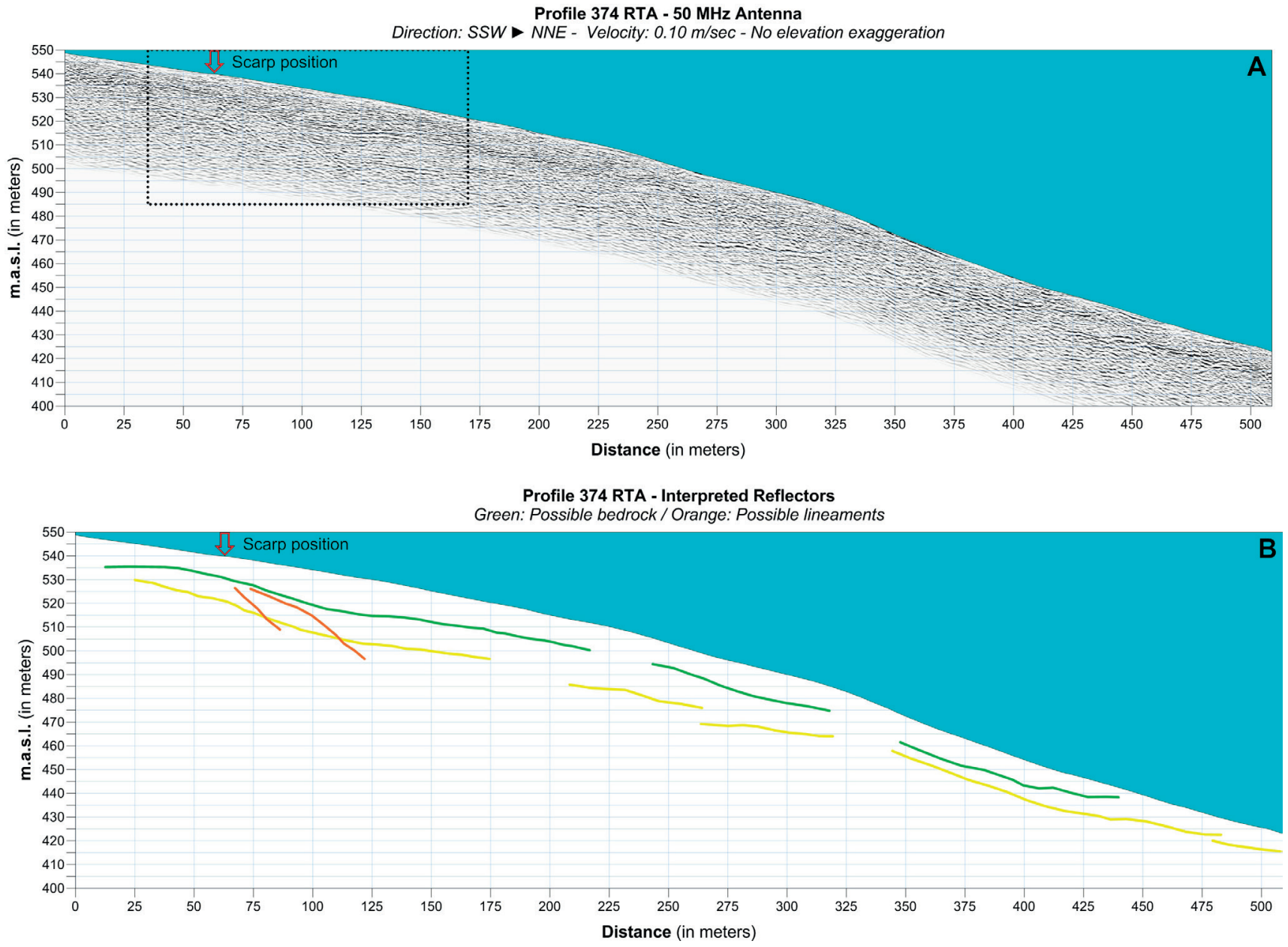

Figure 5. Ground Penetrating Radar (GPR) profile perpendicular to the Nordmannvikdalen fault. (A) The figure shows clean GPR data before interpreted reflectors are indicated. (B) The green reflector most likely represents the bedrock surface below the lodgement till and the yellow reflector is probably from within the bedrock zone. Two prominent much steeper reflectors (orange lines) occur within a c. $10 \mathrm{~m}$-wide zone. The southern (left) reflector can be extrapolated to just a few metres downhill from the surface location of the fault scarp. The rectangular box in the upper panel depicts the location of the zoom-in part of the profile shown in Fig. 6. 


\section{Trenching}

Information from Quaternary geological maps of the area (Bakken, 1983; Tolgensbakk \& Sollid, 1988), in addition to field observations and vertical air-photographs from the internet helped us to choose locations for trenching across the NF escarpment. For 3-5 metres deep trenching we used a 3-ton machine excavator which was transported by helicopter in three separate parts and mounted together in the trenching area. Traditional observations and records of the Quaternary stratigraphy and structures (sediment types, layering, deformation structures, textures, etc.) in each excavated section were then performed, without use of any more sophisticated instruments other than compass, metre measure, knife and spade.

\section{Results from GPR measurements and trenching}

The ground surface in the fault area is characterised by till, with superimposed solifluction features up to a few metres in length and width. Some of the solifluction tongues with their top surfaces reach up to $50-60 \mathrm{~cm}$ above the surrounding terrain, and cryoturbation may occasionally reach deeper than $1 \mathrm{~m}$ below ground surface. The bedrock in this area is dominated by hornblendebiotite schists of the Upper Allochthon's Kåfjord Nappe (Zwaan et al., 2006). The fault is interpreted as a normal fault (Dehls et al., 2000). The quality of the new, migrated, Ground Penetrating Radar (GPR) data is substantially higher than the vintage data interpreted by Dehls et al.
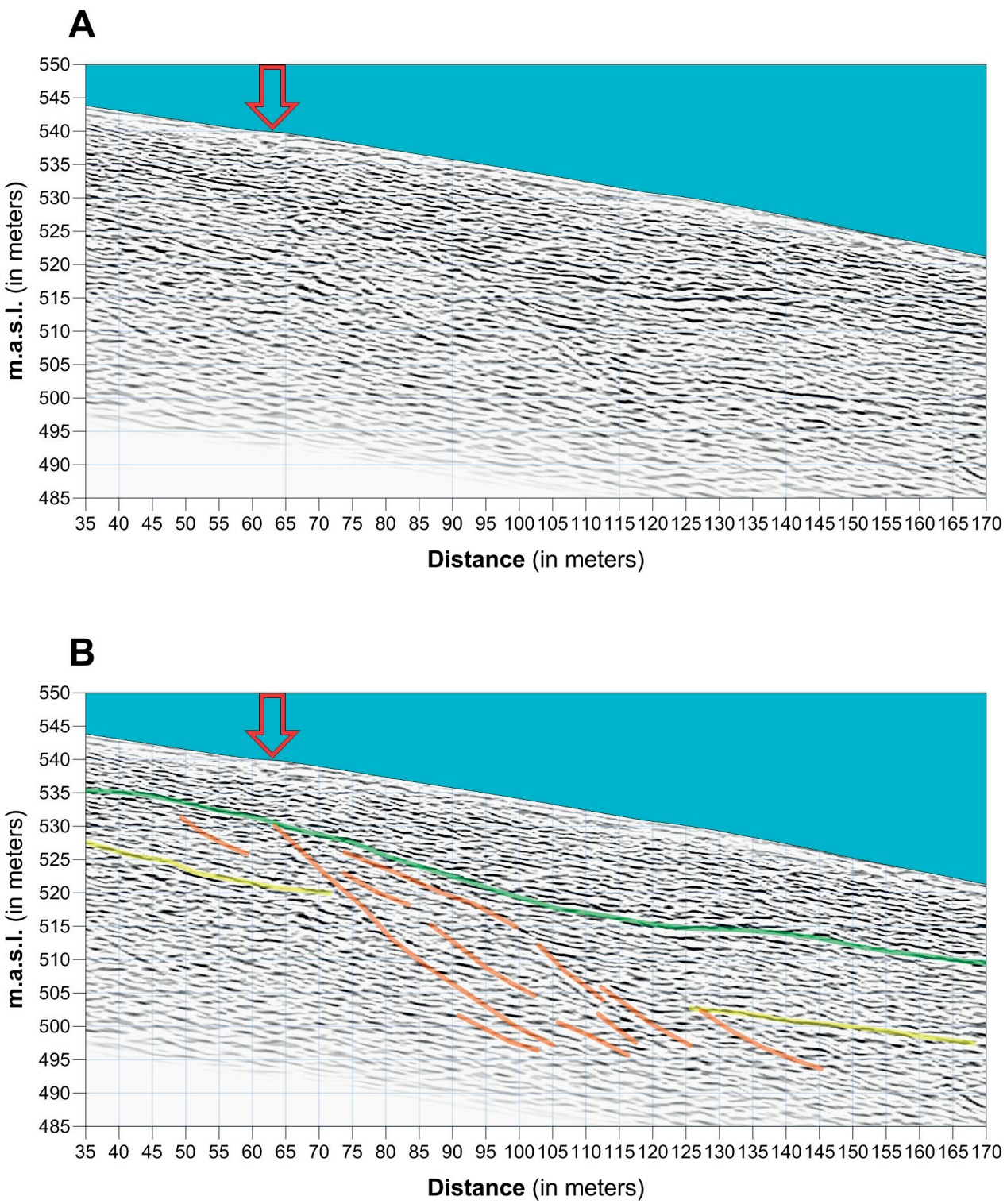

Figure 6. (A, B) Detail of the GPR profile across the Nordmannvikdalen Fault in Fig. 4. The green reflector indicated in the lower panel (B) most likely represents the bedrock surface below the lodgement till. Two to three prominent reflectors (orange lines) occur within a c. $10 \mathrm{~m}$-wide zone. The southern (left) reflector can be extrapolated to just a few metres downhill from the surface location of the fault scarp. 
(2000) and Redfield \& Hermanns (2016). The new GPR profile normal to the fault line shows a possible fault structure that reaches the bedrock surface immediately below the fault scarp. The fault plane has a dip of c. $45^{\circ}$. The total thickness of the loose deposits, mainly glacially derived, on bedrock is apparently c. $8-9 \mathrm{~m}$ just below the fault scarp seen at the surface. The NF seems to have reactivated one of several faults in the bedrock. The faults make up a 10-15 m-wide set of lens-shaped structures (Figs. 5 \& 6). Different faults within this zone seem to have been active as accommodation structures causing ditches semi-parallel to the main scarp. The activated part of the fault complex makes a bend at a depth of $c$. $10 \mathrm{~m}$ below the bedrock surface. The dip of the fault changes from c. $45^{\circ}$ to c. $38^{\circ}$ (Fig. 6 ).

Other postglacial faults in northern Fennoscandia also occur within 10-20 m-wide fault zones, such as the Stuoragurra Fault in Finnmark (Olesen et al., 1992, 2013) and the Isovaara-Riikonkumpu fault complex in Finnish Lapland (Ojala et al., 2017). If the total overburden on bedrock was $100 \%$ frozen during the fault event, then the fault plane (with $45^{\circ} \mathrm{dip}$ ) would probably reach the ground surface a few metres in 'uphill' position, and not where it is really located. This is because a $100 \%$ frozen overburden would behave almost as hard rock during movement, which means that it would act more as a continuation of bedrock than as unconsolidated sediment, all the way through the overburden and to the ground surface. As the fault scarp in the ground surface is located just at or only c. 1-2 m 'uphill' from the vertical projection of the fault line on the bedrock surface, as interpreted from the GPR data (see above), it is likely that a lower, significant part of the overburden was not frozen during the faulting process. However, the upper at least 2-3 metres of the overburden were most likely frozen during the actual faulting process, as described below. Results from the trenching show that a $2-3 \mathrm{~m}$, or more, deep wedge of cryoturbated and soliflucted soil, more than $0.7 \mathrm{~m}$ wide on top, fills a vertical crevice (fissure?) below the fault scarp and below a vertical semi-parallel crevice $10 \mathrm{~m}$ 'downhill' from the fault scarp (Figs. 7, 8, 9 \& 10). The ground surface between the fault scarp, which is up to $1.5 \mathrm{~m}$ high, and the semi-parallel sediment-filled crevice appears as a graben structure since the 'downhill' escarpment of the natural shallow trough overlying the soil sediment wedge is c. $0.2-0.4 \mathrm{~m}$ higher than the 'uphill' escarpment (Figs. 10 \& 11). The graben structure thus seems to be bounded by a conjugate fault set. The vertical crevices were most likely formed when the upper 2-3 $\mathrm{m}$ (or more) of the sediment overburden were frozen, an environment similar to that during initiation of ice-wedge formation during the formation of polygon ground patterns in Arctic areas. These sediment-filled crevices in the Nordmannvikdalen Fault area are similar to large ice-wedge casts, which have developed after melting of large ice wedges that may range from $1 \mathrm{~cm}$ to $3 \mathrm{~m}$ in width and penetrate up to $10 \mathrm{~m}$ downwards into frozen ground (Péwé, 1974). Ice wedge formation and survival through melting seasons is known only from dry Arctic areas where the annual mean temperature is below $-6{ }^{\circ} \mathrm{C}$. The host surficial material along the $\mathrm{NF}$ area is mainly till of basal lodgement type, with characteristics such as striated stones and boulders, lodgement and shear planes, and of matrix-supported and well consolidated character, as observed during the excavations. However, the till here also includes lenses and zones with sand and gravel, and small zones with almost clast-supported character, which altogether gives a variable appearance in vertical sections (Figs. 12 \& 13). Subsequent to the fault event, with formation of the accompanying crevices and graben structure (Fig. 14), the geological process probably proceeded as follows: The open crevices were filled with water (snow?) and some sediments from adjacent loose material -> freezing -> ice wedge formation -> melting down to some dm to $\mathrm{m}$ depth $->$ soil formation (biogenic input, water circulation, chemical alterations) -> freezing of topsoil, cryoturbation and solifluction $\rightarrow>$ repeated melting down to some $\mathrm{dm}$ to $\mathrm{m}$ depth, infilling of soil from the upper part of the overburden, accompanied with further soil formation -> repeated freezing $->$ repeated melting and infilling of soil, and so on. Subsequent to the initial crevice formation, the process was more or less the same as during ice-wedge formation in Arctic areas, with an ice-wedge cast (fossil ice wedge) as end product where enough melting in time and depth has occurred. Finally, melting down to more than 2-3 m depth resulted in cavities and/or tunnels appearing below the sediment wedges (Figs. 8, 9 \& 10), due to melting of ice and overlying blocking of the crevice from coarse-grained material in the lower part of the sediment wedges.

Some of these cavities and/or tunnels are still open, whereas many of these are presumed to have been filled with sediments, leaving the ground surface with natural shallow troughs following on top of the respective crevices. This interpretation is also compatible with the results from the c. $5 \mathrm{~m}$-deep trenching by Bakken (1983). When were the sediment wedges formed? Most of them may have been formed in the early part of the Holocene, but not before significant soil formation had taken place, i.e., after several hundred years. Infilling of sediments, cryoturbation and solifluction in the scarp slope in several phases, in combination with soil formation, comprise the further geological processes. These may have continued for several hundred years, and have continued to some extent through the entire Holocene. The strongest cryoturbation most likely took place in the cold phases (with ice growth in the high ground glacier areas) during Holocene, as for example c. 10,200, 8200, and 2500 years B.P., and during the Little Ice Age (16201920 A.D.).

Redfield \& Hermanns (2016) interpreted a tectonically active N-S-trending fault in the outer Lyngen Fjord from recordings at the NORSAR seismic array in Karasjok, which is located $200 \mathrm{~km}$ to the east. The University 
of Bergen includes additional recordings from their seismic stations in Tromsø and Kautokeino, located 60 and $140 \mathrm{~km}$ to the west and southeast, respectively. These improved epicentres (Fig. 2) lend no support for the Lyngen Fjord active fault. Explosion filtering of the earthquakes removes much of the apparent seismicity in the area (shown in yellow in Fig. 2). The filter removes events less than magnitude 2.0 that occurred between 08:00 in the morning and 18:00 in the afternoon (C. Lindholm, pers. comm., 2017). Approximately $40 \%$ of the real earthquakes will also be removed in this process.

InSAR anomalies of several $\mathrm{mm}$ across the NWSE-trending valleys of Kåfjorddalen, Skibotndalen
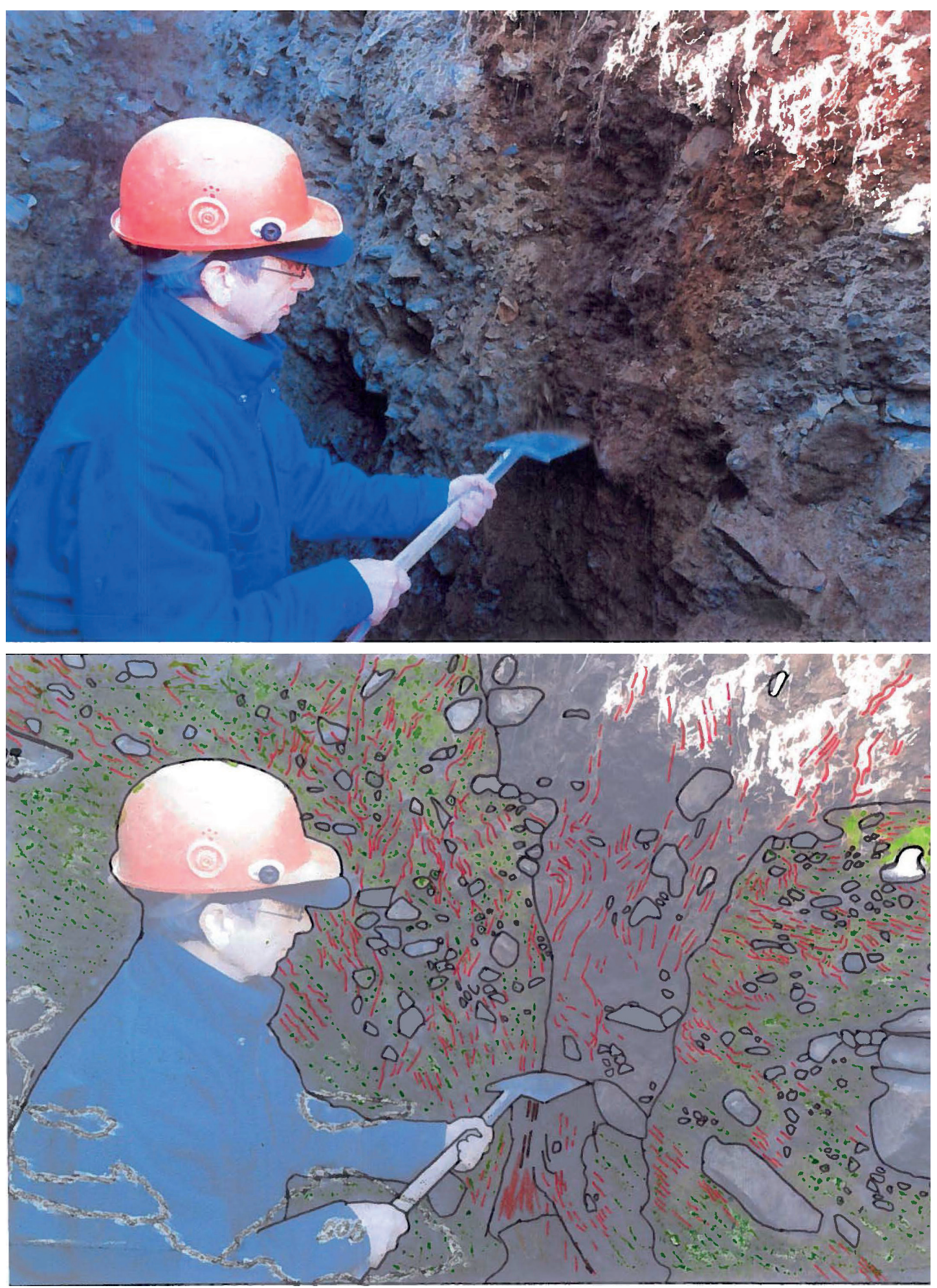

Figure 7. Section across and normal to the fault scarp, trench 1. A deep soil wedge penetrates the hosting compact lodgement till there. Fragmented line segments in the lower panel indicate shear and/or sliding planes. The till does not include distinct sediment horizons which can be followed from one side to the other of the sediment wedge. 


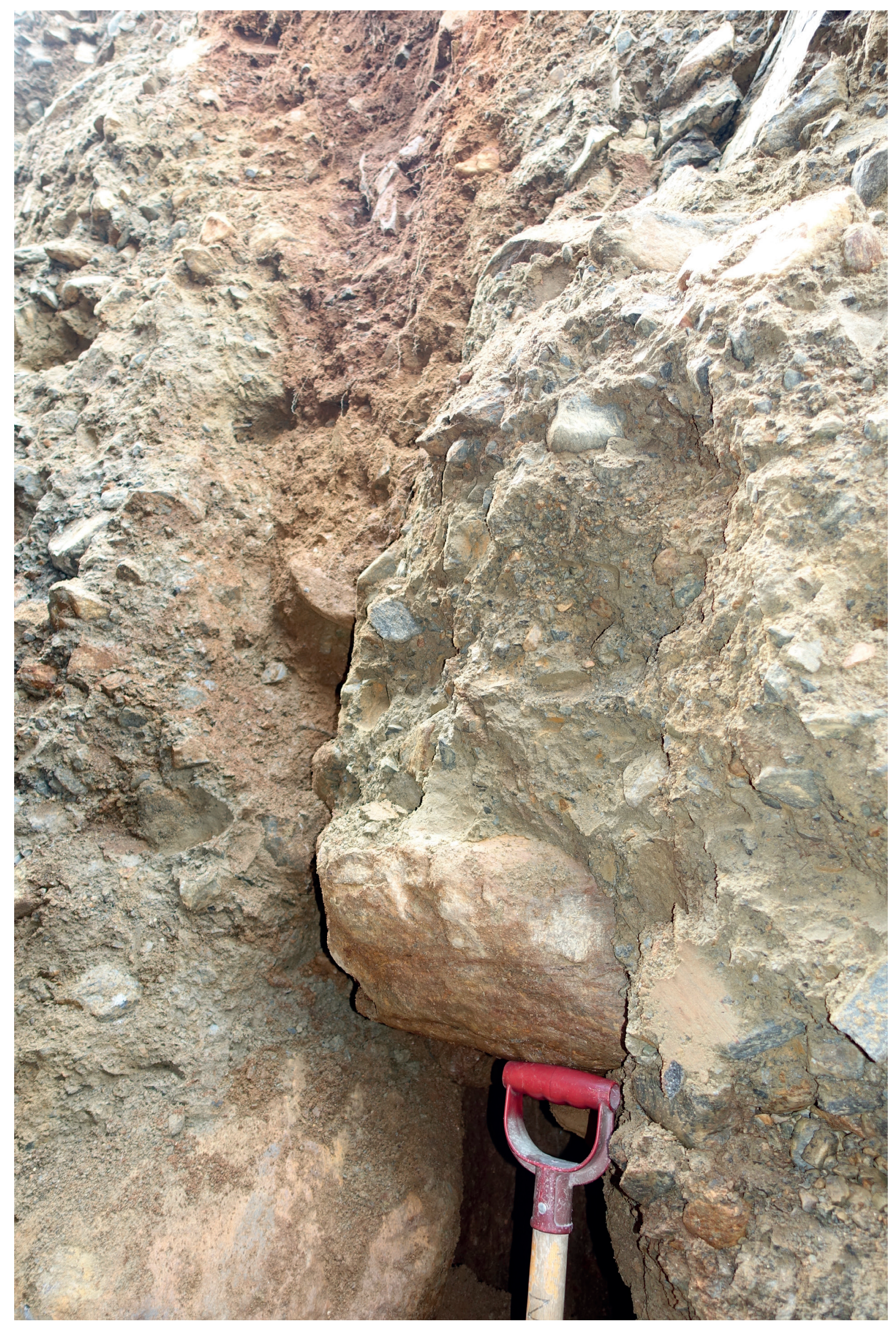

Figure 8. Cavity under coarse clast material at depth in sediment wedge filling the fault crevice recorded in trench 1. 

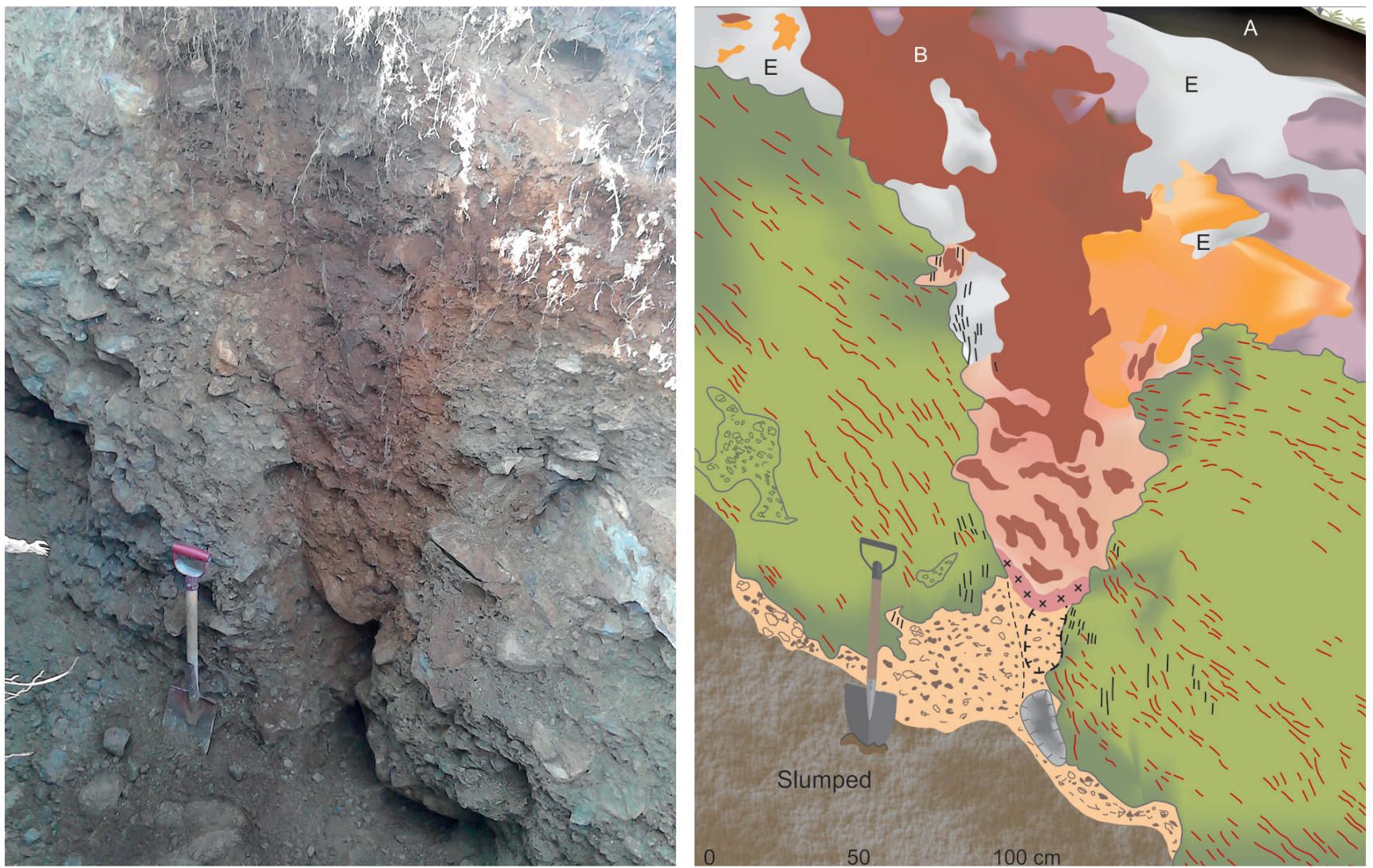

Figure 9. (A; left) Section across and normal to the fault scarp, trench 1, Nordmannvikdalen - with a sediment wedge of strongly cryoturbated and disturbed soil, ending in a cavity in the lower part (below the wedge apex). (B; right) Red line segments in the outline indicate a combination of depositional, sliding and shearing structures in the till, whereas blue line segments indicate sliding, mainly from vertical displacement during the faulting event, but possibly also later during slumping and infilling of sediments in the fault crevice and underlying cavities.

and Signaldalen (Osmundsen et al., 2009; Redfield \& Hermanns, 2016) have been used as arguments for active faults along these valleys. These findings are, however, inconsistent with the present-day seismicity in the area as shown in Fig. 2.

Interseismic fault creep has been recorded along active plate boundaries, e.g., along the strike-slip faults belonging to the San Andreas fault system in California (Sylvester, 1995). However, aseismic faults are relatively rare in intraplate regions. The lack of evidence for active tectonics in the northern Troms area was also pointed out by Olesen et al. (2013).

\section{Discussion}

Redfield \& Hermanns (2016) used the empirical relationship determined from a global dataset of earthquake magnitudes and the corresponding fault dimensions by Wells \& Coppersmith (1994) to reject the NF as a tectonic fault. Wells \& Coppersmith (1994) calculated a regression line from the observed fault length and offset compiled from historic earthquakes. The original observation data show, however, more than one order of variation along this line. The fact that the fault displacement to fault length ratio is an order of magnitude higher than the average for earthquakerelated faulting is consequently not a valid criterion for discarding the NF as a tectonic fault. The anomalously high scarps compared to fault length have already been pointed out, e.g., by Muir-Wood (1989). Fenton (1994) took this variation into consideration when they concluded that most postglacial faults have a displacement-length ratio between 0.00001 and 0.001 . The NF ratio $(1.5 / 1300=0.00115)$ falls just above the highest part of this range. The Pasmajärvi Fault in northern Finland has a height/length ratio of $0.0008-$ 0.0016 (Kujansuu, 1964). The N-S trending and NE-SW sections of the Ismunden Fault in Central Sweden have height/length ratios of $6 / 3500=0.0046$ and $8 / 22,000$ $=0.00036$ (Berglund \& Dahlström, 2015), respectively. These examples show that the height/length ratio of the Nordmannvikdalen Fault is high but not anomalous compared to other postglacial faults in northern Fennoscandia. The NF is the only structure within the Kåfjord 1:50,000 map-sheet that offsets the Quaternary overburden (Bakken, 1983; Sollid \& Tolgensbakk, 1988). Redfield \& Hermanns (2016) argued, however, that the $\mathrm{NF}$ is located between two DSGSDs at the mountains of Kistefjellet and Nordmannviktinden. Tolgensbakk \& Sollid (1988) classified these phenomena as glacial- 


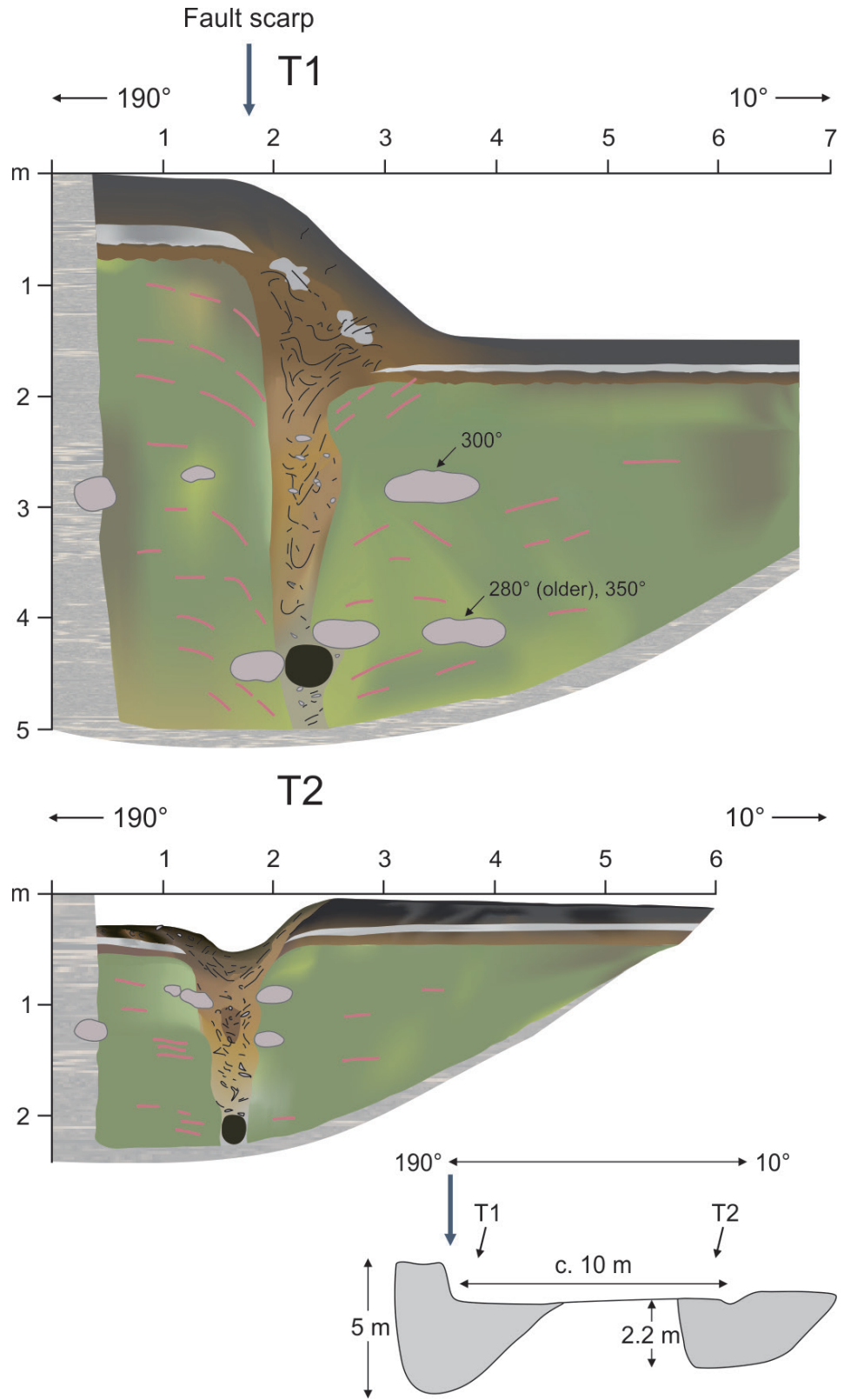

Figure 10. Outline of the first two trenches (T1 and T2) in Nordmannvikdalen. The orientations of the sections are normal to the fault. Notice the cavity at depth in the lower part of both sediment wedges. The combined sections indicated below illustrate a cross-section of the grabenlike structure appearing in Fig. 11.

formed escarpments. Neither Bakken (1983), nor Redfield \& Hermanns (2016) reported any evidence of displacement of the Quaternary overburden or bedrock surface along the suggested DSGSDs and there is consequently not much support for the interpretation of deep-seated gravitational slope deformation at these mountains. We apply the criteria by Fenton (1994) and Muir-Wood (1993) for the identification of postglacial faulting:

1) Offset of an originally continuous surface or sedimentary sequence of postglacial or late-glacial age. The surface of the lodgement till is offset along an at least $1.3 \mathrm{~km}$-long linear to curvilinear escarpment, which is accompanied in some parts by an adjacent, parallel shallow trough. Dehls et al. (2000) fit a plane with a dip of $28^{\circ}$ through this line revealing that the structure is not a shallow structure in the Quaternary overburden as suggested by Redfield \& Hermanns (2016).

2) Reasonably consistent direction and amount of slip along the length of the fault. The height of the fault decreases gradually from c. $1.5 \mathrm{~m}$ in the SE to c. $0.2 \mathrm{~m}$ in the NW (Dehls et al., 2000; Redfield \& Hermanns, 2016).

3) The ratio of displacement to overall length of the feature should be less than 1/1,000. For most faults this ratio is between $1 / 1,000$ and $1 / 10,000$. The 


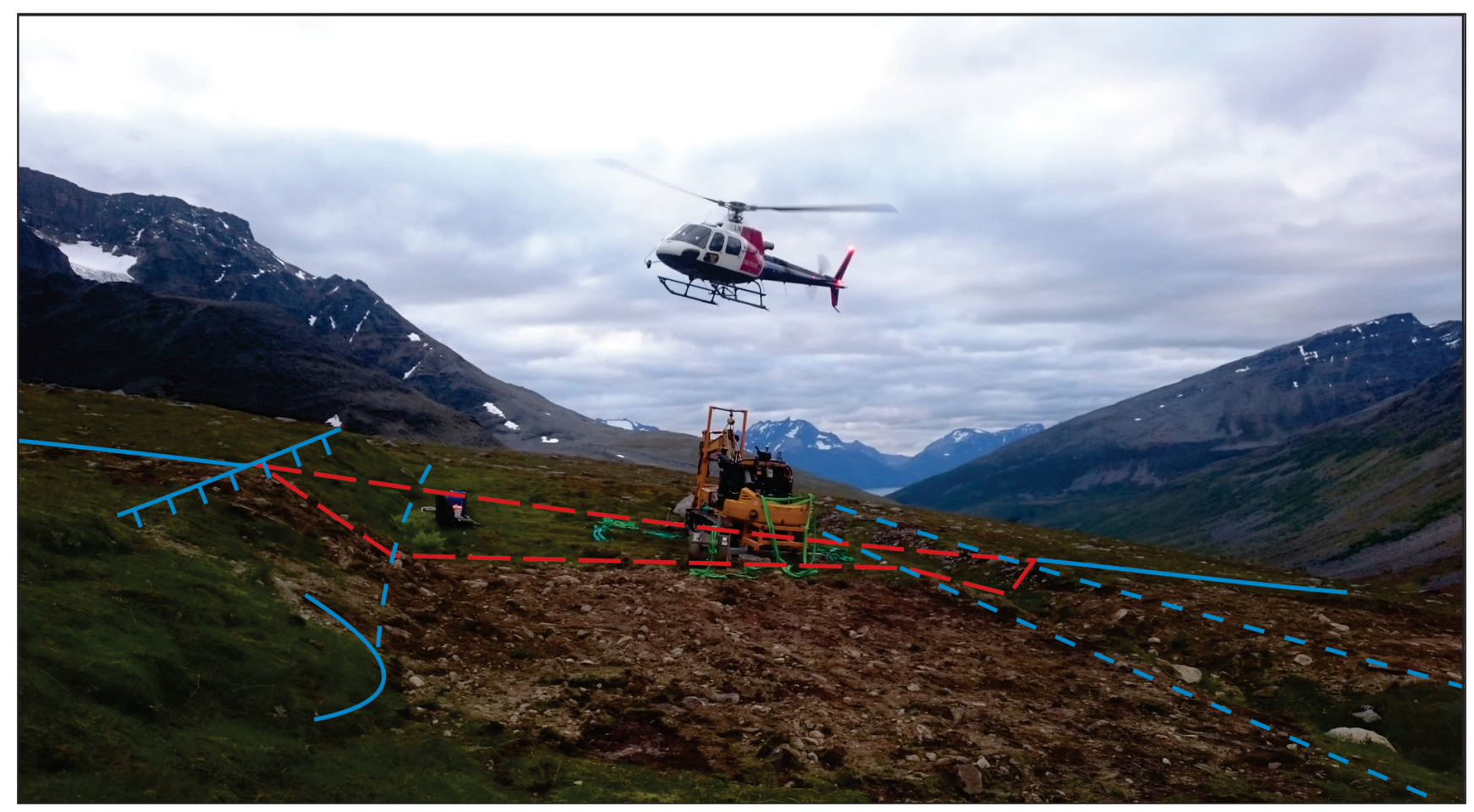

Figure 11. A graben-like structure appears in a downhill surface profile normal to the fault scarp (hatched blue line to the left) and the semiparallel trough (between stippled blue lines to the right). Notice also the solifluction tongues which are masking the fault scarp in a narrow zone to the left.

Nordmannvikdalen Fault has a ratio of approximately $1 / 1,000(1.5 \mathrm{~m} / 1,300 \mathrm{~m})$. The fault is most likely longer than $1.3 \mathrm{~km}$ since the height of the fault scarp is c. $1.5 \mathrm{~m}$ where the fault encounters the boulder fields at the foot of Kistefjellet and less than $0.5 \mathrm{~m}$ north of Nordmannviktinden. It is not possible to trace the continuation of the fault scarp at these locations. It is, however, unlikely that the fault reached the surface for a longer distance than $2 \mathrm{~km}$.

4) Exclusion of gravity-induced sliding as the driving mechanism of faults in areas of moderate to high relief. The fault is sub-parallel to the Nordmannvikdalen valley. The terrain has an average slope of c. $14^{\circ}$ between the escarpment and the valley floor. The slope is gentle when comparing with the mountainous areas in the vicinity of Nordmannvikdalen. It is not likely that the fault scarp is controlled by low-friction graphite schists since the fault is not parallel to the layering or foliation of the bedrock (Dehls et al., 2000). Ojala et al. (2017) reported graphite schist from drillholes through the postglacial IsovaaraRiikonkumpu fault in northern Finland. We have found evidence for neither released high-pressure fluids nor gases that could have reduced the friction of the structure before faulting. This phenomenon is reported from the reverse Stuoragurra Fault in Finnmark by Dehls et al. (2000). The elevation difference between the fault scarp and valley bottom is c. $200 \mathrm{~m}$. Gravity-induced sliding is less likely to occur when the elevation difference is less than 300 m (Varnes et al., 1989). Other DSGSDs in Norway are usually located $400-1100 \mathrm{~m}$ above the floor of the fjord or the valley (like the Berill $(1100 \mathrm{~m})$, Nordnesfjellet $(900 \mathrm{~m})$, Kvasshaugen $(400 \mathrm{~m})$ and Åkneset $(1100 \mathrm{~m}))$. The slope of these deformation structures usually has an angle of c. $30^{\circ}$, i.e., more than twice as steep as the terrain below the Nordmannvika Fault. The apparent slope angle of $34-38^{\circ}$ in Fig. 10 of Redfield \& Hermanns (2016) is caused by the 2.5 exaggeration factor of the vertical axis.

5) No signs of glacial modification (such as striation or ice-plucking) of fault scarps, especially those controlled by banding, bedding or schistosity. There is no sign of glacial modification of the fault scarp, which implies that a warm-based erosive glacier has never covered the fault scarp. Warm-based ice characterised deglaciation of all Norwegian fjord valleys, including Nordmannvikdalen. The NF is therefore of postglacial age and was formed subaerially, not subglacially. The Nordmannvikdalen valley was deglaciated shortly before the Younger Dryas chronozone (12.911.5 kyr BP) (Dahl \& Sveian, 2004), which consequently represents a maximum age of the fault. The scarp is locally modified by Holocene solifluction.

6) Exclusion of mechanisms such as glaciotectonics (ice push features), collapse due to ice melting and 


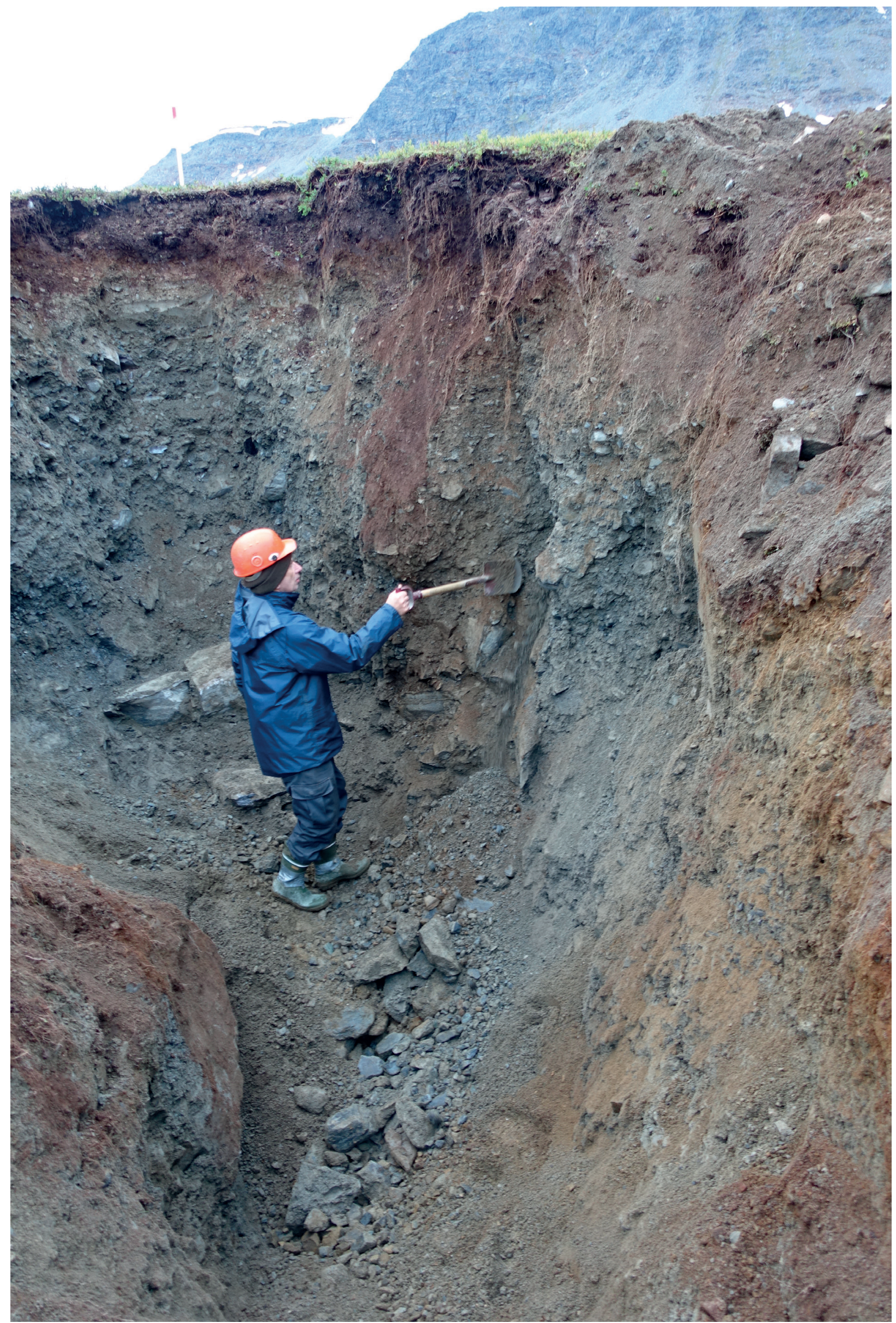

Figure 12. Nordmannvikdalen trench 3, southern (left) and western (right) walls. For location, see Fig. 3, close to the end in the southeast. 


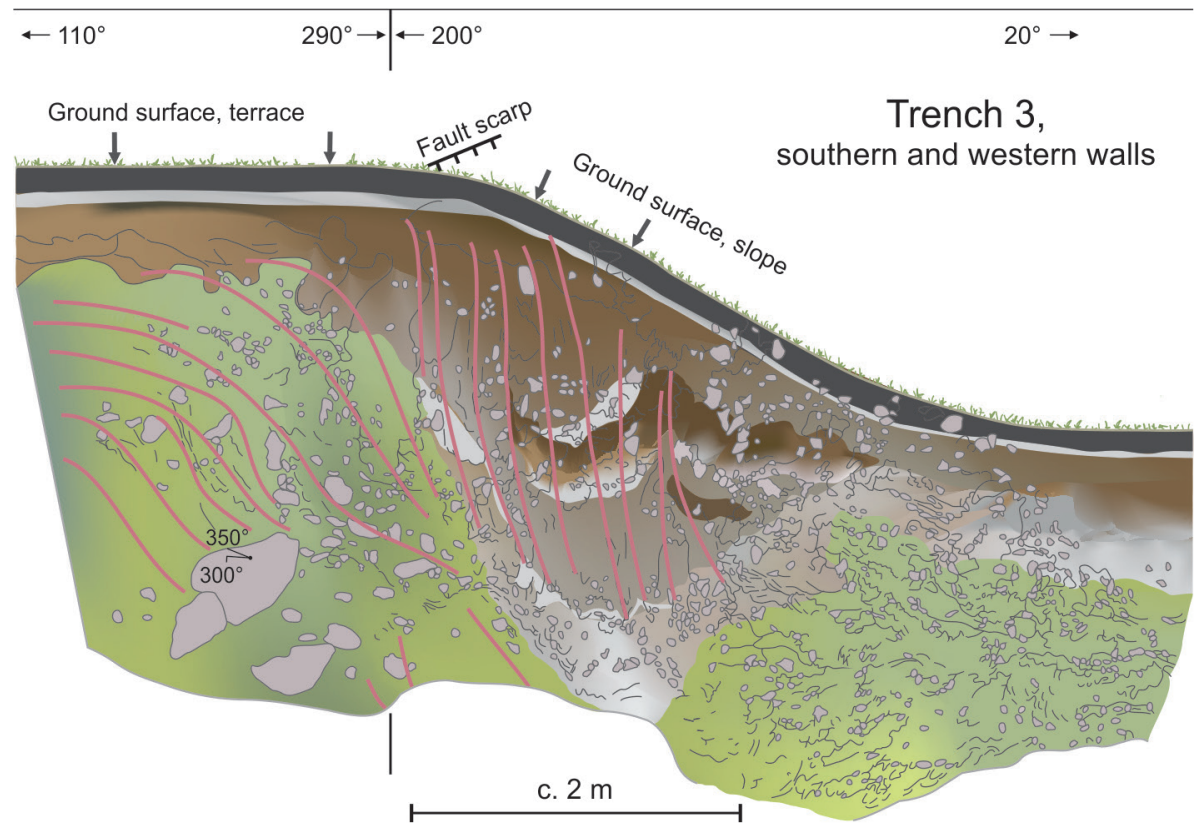

Figure 13. Outline of combined sections in trench 3, southern (left) and western (middle and right) walls. The wall sections are here slightly rotated around a vertical axis (vertical black line segments), so that a 3D-view of the walls may be imagined from this $2 D$-view. The reddish lines represent a combination of depositional, shearing, sliding and deformational planes. Also shown, with brownish colours, is the collapsed and further cryoturbated soil, and, with greenish colour, the lodgement till. Glacial striations towards $300^{\circ}$ (older) and $350^{\circ}$ on a big boulder to the left are also indicated.

differential compaction or deposition over a preexisting erosional scarp being the cause of an apparent offset in overburden. The Quaternary overburden consists of massive lodgement till with no sign of differential compaction or deposition over the scarp, except in the adjacent vertical wedge zones where the postglacial infill sediments are clearly less compacted.

Topographical map data show that the downhill surface gradient is less than 20 degrees in the area where the $\mathrm{NF}$ is located, which is much less than suggested by Redfield \& Hermanns (2016) and is itself at odds with their hypothesised DSGSD origin of the NF. The results from our GPR measurements, observations in the field and trenching showed in addition that:

- Bedrock structures with reflectors sloping with relatively steep angles, up to $45^{\circ}$, are traceable up to the bedrock-overburden interface at c. $10 \mathrm{~m}$ depth close to the NF location. One of these, at $45^{\circ}$ dip angle, reaches the bedrock surface just a few metres downhill from the NF scarp, and is likely to represent the NF fault plane interception in the GPR profile.

- The extended trenching, both vertically and horizontally, of the previous trench that Redfield \& Hermanns (2016) used as a basis for their observations, showed that their record did not reach deeper than within the cryoturbated soil zone, which did not give any information of other possible deformation or displacement associated with faulting.
- Similarly as found by Bakken (1983) in the western part of the fault scarp, the new trenching in the middle of the scarp showed that vertical sediment wedges occurred in lodgement till just under the NF scarp, and also under a trough lineament semiparallel to and c. $10 \mathrm{~m}$ separated from the NF scarp. The zone between these features appears as a shallow graben structure with conjugate normal fault boundaries. Cavities occur also under the apex of the sediment wedges.

- Trenching close to the eastern end of the fault scarp showed a wider collapsed zone ( $>2 \mathrm{~m}$ wide) just under and downhill from the fault scarp (Figs. $12 \& 13)$. The topsoil in and just under the scarp slope is both cryoturbated and further collapsed to a depth of at least 2.5-3 m. These features, together with the sediment wedges and cavities below, as mentioned above, indicate initially frozen ground (permafrost) and subsequent melting, sediment infilling and collapse of sediments in open semilinear cracks, longer than any semi-linear frost cracks reported from pattern ground fields in Arctic areas, and also water circulation at depth, in combination with periods of cryoturbation in the top soil along the NF and semi-parallel structures. The evidence of permafrost conditions during the faulting event indicates that the age of the fault is most likely Younger Dryas, which is the last and only known interval since deglaciation of this area when permafrost conditions reached several metres depth.

- Solifluction features are abundant in the NF area and 

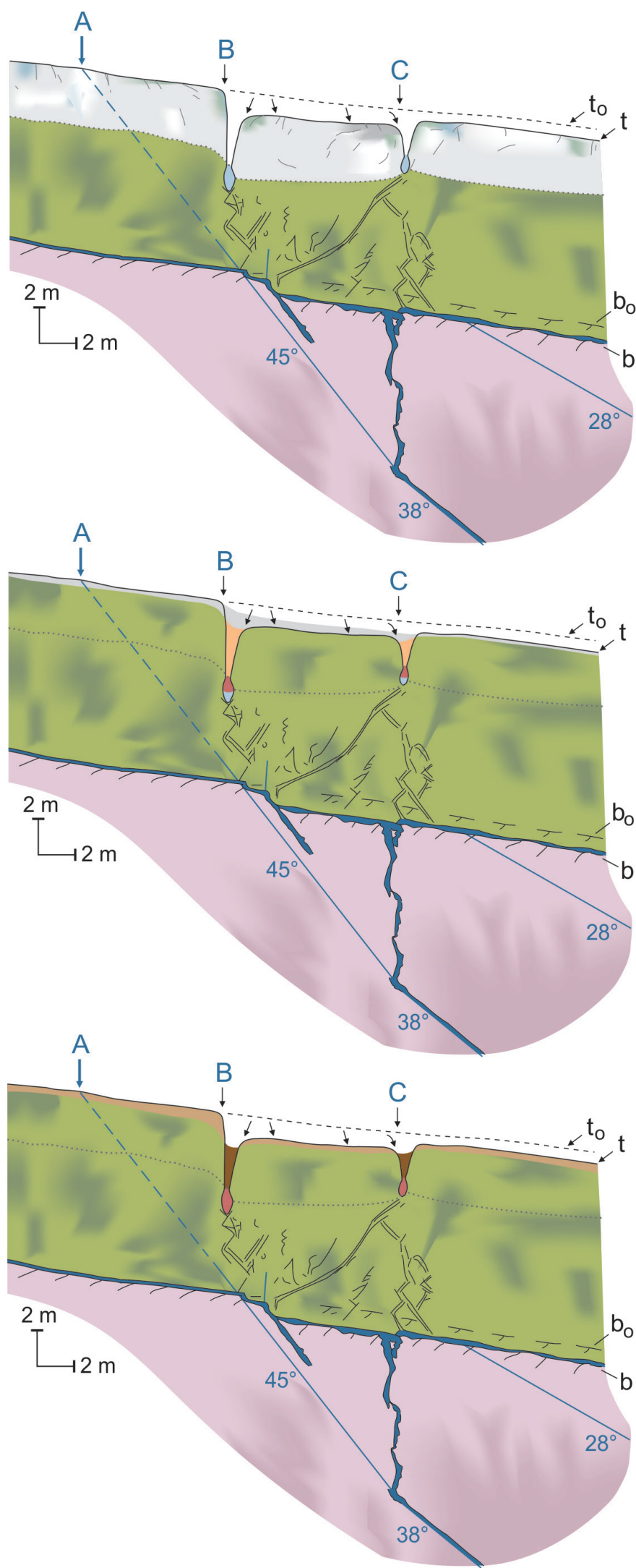

Figure 14. Outline of a profile through the overburden based on data from trenches 1 and 2 in Nordmannvikdalen, and interpretation of the ground penetrating radar profile shown in Figs. 5 and 6. The orientation of the outlined profile is normal to the fault. A - This indicates the assumed location of surface traces of the fault if the sediment overburden was totally frozen (deep permafrost) during the faulting event. $B-$ position of the Nordmannvikdalen fault scarp, just a few metres upslope from the vertical projection of the fault plane outgoing in the bedrock surface inferred from the georadar data (see Fig. 6). C-position of the semi-parallel trough (see Fig. 10). The letters $t_{0}$ and $t$ indicate sediment surface position and $b_{0}$ and $b$ bedrock (pink) surface position before and after the faulting event, respectively. Steepness (in degrees) of bedrock reflectors which may represent fault planes also indicated.
Fault event-

- Frozen upper part

- Cracking, crevice formations, slumping of sediments, ice wedge formation

\section{Early stage-}

- Melted to at least 2-3 m depth, initial infilling of crevices, soil formation

Today-

- Sediment wedges of cryoturbated soil 
the fault scarp has locally clearly been modified by periglacial processes, but not formed by them. Since even Redfield \& Hermanns (2016) actually ruled out their own hypothesis of a DSGSD origin for the NF scarp, we can just support their discussion; the slope angle is simply much too low, and a different mechanism is needed to lead to the formation of the at least $1.3 \mathrm{~km}$-long NF scarp, and that is a tectonic mechanism.

Lagerbäck \& Sundh (2008) argued that the Weichselian deglaciation was unique since no faulting has been observed subsequent to the previous glaciations in northern Sweden. Landforms generated during these glaciations can still be observed in northern Sweden since the inland ice was frozen to the ground during most of the glacial periods, except in some areas where such features may be strongly deformed or eliminated, as e.g., in zones with series of long flutes or drumlins (Nordkalott Project, 1986), which indicate ice streaming and therefore warm-based ice with at least partially erosive glacier conditions in later parts of the last glaciation. Pore pressure building up under a thick ice and a thick permafrost zone could have contributed to the anomalously large horizontal stress and low vertical stress in the bedrock at the time of deglaciation as suggested by Muir-Wood (1989) and Lagerbäck \& Sundh (2008). The indications of at least partial permafrost conditions during the postglacial faulting in Nordmannvikdalen support this conclusion.

\section{Conclusions}

The Nordmannvikdalen Fault fulfils all six criteria defined by Fenton (1994). We therefore maintain that the structure should be classified as (A) 'Almost certainly neotectonics' as proposed by Dehls et al. (2000) and Olesen et al. $(2004,2013)$. The elevation difference of $200 \mathrm{~m}$ and the $14^{\circ}$ average angle of the slope are too small to induce gravitational sliding. The trenching of the fault scarp clearly shows that the scarp has formed during faulting and cannot be related to overburden creep processes. The length of the fault scarp of at least $1.3 \mathrm{~km}$ disqualifies it as a feature related to cracking of the ground surface during an abrupt extreme temperature fall in Arctic areas, since all such reported or known and mapped linear features in patterned Arctic ground are less than a few tens of metres in length (Ballantyne \& Harris, 1994). However, when cracking of the frozen ground during the faulting event had happened, then the further development with ice wedge and subsequent ice-wedge cast formation proceeded similarly as is known from Arctic areas. Consequently we find no support for the suggestion by Redfield \& Hermanns (2016) to downgrade the fault to (E) 'very unlikely to be neotectonics', and nor do we find any evidence for the numerous active faults in the northern Troms area as suggested by these authors (op.cit.). The final conclusion is that we still favour a tectonic origin for the Nordmannvikdalen Fault. The magnitude of the earthquake related to the Nordmannvikdalen faulting was in the range 5.3-6.5 when comparing it with the length and displacement of contemporary earthquakes (Wells \& Coppersmith, 1994). The wide range of the estimate is related to the anomalous height/length ratio of the fault.

Acknowledgements. This study has been supported in the framework of the NEONOR2 project by the Norwegian Research Council, the Geological Survey of Norway, the Norwegian Petroleum Directorate the Norwegian Mapping Authority, AkerBP, DEA Norge, E.ON Norge, INEOS, Lundin Norway, Maersk Oil Norway, Norske Shell, Norwegian Energy Company (Noreco), Repsol Exploration Norge, Statoil (now Equinor) and VNG Norge. Tom Gunnar Isaksen og Roy Steinar Karlsen from Manndalen Maskin carried out the trenching of the Nordmannvikdalen Fault. Helitrans transported the excavator from Nordmannvika to the trenching site in Nordmannvikdalen. The land owners Anette Susanne Lyngmo Seppäla and Veli-Matti Rikhart Seppäla and the municipality of Kåfjord granted permission and provided support for the trenching. Changes based on comments from the two reviewers Winfried Dallmann and Raimo Sutinen have significantly improved the manuscript. Irene Lundqvist drafted Figs. 7, 9-11 and 13-14. We express our sincere thanks to all these persons, companies and institutions.

\section{References}

Bakken, A.J.H. 1983: Nordmannvikdalen kvartaergeologi og geomorfologi. MSc thesis, University of Oslo, $126 \mathrm{pp}$.

Ballantyne, C.K. \& Harris, C. 1994: The Periglaciation of Great Britain. Cambridge University Press 1994, 330 pp.

Beanland, S., Blick, G.H. \& Darby, D.J. 1990: Normal faulting in a back arc basin: Geological and geodetic characteristics of the 1987 Edgecumbe earthquake. Journal of Geophysical Research 95, 46934707. https://doi.org/10.1029/JB095iB04p04693.

Berglund, M. \& Dahlström, N. 2015: Postglacial fault scarps in Jämtland, central Sweden. Geologiska Föreningens i Stockholm Förhandlingar 137, 339-343.

Braathen, A., Blikra, L.H., Berg, S.S. \& Karlsen, F. 2004: Rock-slope failures of Norway; type, geometry, deformation mechanisms and stability. Norwegian Journal of Geology 84, 67-88.

Dahl, R. \& Sveian, H. 2004: Ka dokker mein førr stein! Geologi, landskap og ressurser $i$ Troms. Norges geologiske undersøkelse, 154 pp.

DECO Geophysical 2005: RadExplorer 1.4. The software for GPR data processing and interpretation. User Manual.

Dehls, J.F., Olesen, O., Olsen, L. \& Blikra, L.H. 2000: Neotectonic faulting in northern Norway; the Stuoragurra and Nordmannvikdalen postglacial faults. Quaternary Science Reviews $19,1447-1460$.

Fenton, C.H. 1994: Postglacial faulting in eastern Canada. Geological Survey of Canada Open file Report 2774, 98 pp.

Holmsen, G. 1916: Om strandlinjers fald omkring gabbro-omraader (Summary in English). Norsk Geologisk Tidsskrift 4, 7-20.

Jol, H.M. 2009: Ground Penetrating Radar Theory and Applications. Elsevier Science, $544 \mathrm{pp}$.

Kujansuu, R. 1964: Nuorista sirroksista Lapissa. Summary: Recent faults in Lapland. Geologi 16, 30-36. 
Lagerbäck, R. \& Sundh, M. 2008: Early Holocene faulting and paleoseismicity in northern Sweden. Geological Survey of Sweden Research Paper C 836, 1-84.

Mauring, E., Olesen, O., Rønning, J.S. \& Tønnesen, J.F. 1997: Groundpenetrating radar profiles across post-glacial faults at Kåfjord, Troms, and Fidnajohka, Finnmark. NGU Report 97.174, $11 \mathrm{pp}$.

Mikko, H., Smith, C.A, Lund, B., Ask, M. \& Munier, R. 2015: LiDARderived inventory of 25 post-glacial fault scarps in Sweden. Geologiska Föreningens i Stockholm Förhandlingar 137, 334-338.

Muir-Wood, R. 1989: Extraordinary deglaciation reverse faulting in northern Fennoscandia. In Gregersen, S. \& Basham, P.W. (eds.): Earthquakes at North-Atlantic Passive Margins: Neotectonics and Postglacial Rebound, Kluwer Academic Publishers, Dordrecht, The Netherlands, pp. 141-173.

https://doi.org/10.1007/978-94-009-2311-9_10.

Muir-Wood, R. 1993: A review of the seismotectonics of Sweden. Swedish Nuclear Fuel and Waste Management Company (SKB) Technical Report 93-13, 225 pp.

Nordkalott Project 1986: Map of Quaternary geology, sheet 2: Glacial geomorphology and paleohydrography, Northern Fennoscandia, scale 1:1,000,000, Geological Surveys of Finland, Norway and Sweden.

Ojala, A.E.K., Mattila, J., Ruskeeniemi, T., Palmu, J.K., Lindberg, A., Hänninen, P. \& Sutinen, R. 2017: Postglacial seismic activity along the Isovaara-Riikonkumpu fault complex. Global and Planetary Change 157, 59-72. https://doi.org/10.1016/j.gloplacha.2017.08.015.

Olesen, O. 1988: The Stuoragurra Fault, evidence of neotectonics in the Precambrian of Finnmark, northern Norway. Norwegian Journal of Geology 68, 107-118.

Olesen, O., Roberts, D., Henkel, H., Lile, O.B. \& Torsvik, T.H. 1990: Aeromagnetic and gravimetric interpretation of regional structural features in the Caledonides of West Finnmark and North Troms, northern Norway. Norges geologiske undersøkelse Bulletin 419, 1-24.

Olesen, O., Henkel, H., Lile, O.B., Mauring, E. \& Rønning, J.S. 1992: Geophysical investigations of the Stuoragurra postglacial fault, Finnmark, northern Norway. Journal of Applied Geophysics 29, 95-118. https://doi.org/10.1016/0926-9851(92)90001-2.

Olesen, O., Blikra, L.H., Braathen, A., Dehls, J.F., Olsen, L., Rise, L., Roberts, D., Riis, F., Faleide, J.I. \& Anda, E. 2004: Neotectonic deformation in Norway and its implications: a review. Norwegian Journal of Geology 84, 3-34.

Olesen, O., Bungum, H., Dehls, J., Lindholm, C., Pascal, C. \& Roberts, D. 2013: Neotectonics, seismicity and contemporary stress field in Norway - mechanisms and implications. In Olsen, L., Fredin, O. \& Olesen, O. (eds.): Quaternary Geology of Norway, Geological Survey of Norway Special Publication 13, pp. 145-174.

Osmundsen, P.T., Henderson, I., Lauknes, T.R., Larsen, Y., Redfield, T.F. \& Dehls, J. 2009: Active normal fault control on landscape and rock-slope failure in northern Norway. Geology 37, 135-138. https://doi.org/10.1130/G25208A.1.

Palmu, J.P., Ojala, A.E.K., Ruskeeniemi, T., Sutinen, R. \& Mattila, J. 2015: LiDAR DEM detection and classification of postglacial faults and seismically-induced landforms in Finland: a paleoseismic database. Geologiska Föreningens $i$ Stockholm Förhandlingar 137, 344-352.

Péwé, T.L. 1974: Geomorphic processes in polar deserts. In Smiley, T.L. \& Zumberge, J.H. (eds.): Polar Deserts and Modern Man, Tucson, University of Arizona Press, pp. 33-52.

Redfield, T.F. \& Hermanns, R.L. 2016: Gravitational slope deformation, not neotectonics: Revisiting the Nordmannvikdalen feature of northern Norway. Norwegian Journal of Geology 96, $1-29$.

Sollid, J.L. \& Tolgensbakk, J. 1988: Kvartærgeologisk og geomorfologisk kartlegging på Svalbard og fastlands-Norge. Abstract, Nordic Geological Winter-Meeting, Copenhagen, p. 380-381.
Sylvester, A.G. 1995: Nearfield vertical displacement in the creeping segment of the San Andreas fault, central California, 1975 to 1994. Tectonophysics 247, 25-47. https://doi.org/10.1016/0040-1951(94)00244-4.

Tolgensbakk, J. \& Sollid, J.L. 1988: Kåfjord, kvartærgeologi og geomorfologi 1634 II, scale 1:50,000, Geografisk institutt, University of Oslo.

Varnes, D.J., Radbruch-Hall, D.H. \& Savage, W.Z. 1989: Topographic and structural conditions in areas of gravitational spreading of ridges in the Western United States. USGS Professional Paper 1496, $28 \mathrm{pp}$.

Vestøl, O., Ågren, J., Steffen, H. in prep: A new land uplift model for Fennoscandia and the Baltic Region.

Wells, D.L. \& Coppersmith, K.J. 1994: Empirical relationships among magnitude, rupture length, rupture area, and surface displacement. Bulletin of the Seismological Society of America 84, 974-1002.

Yeats, R.S., Sieh, K. \& Allen, C.R. 1997: The geology of earthquakes. Oxford University Press, New York, 568 pp.

Zwaan, K.B., Dangla, P. \& Quenardel, J.M. 2006: Berggrunnskart Kåfjord 1634 II, scale 1:50,000, Norges geologiske undersøkelse. 